\title{
Dinamika Psikologis yang Mendorong Seseorang Melakukan Pembunuhan: Studi Kasus Pada Narapida dengan Kasus Pembunuhan Berencana di Lembaga Pemasyarakatan X
}

\author{
I Dewa Gede Udayana Putra \\ Magister Psikologi Profesi, Fakultas Psikologi, Universitas Surabaya \\ dewaudayana92@gmail.com \\ Hartanti \\ Magister Psikologi Profesi, Fakultas Psikologi, Universitas Surabaya \\ hartanti@staff.ubaya.ac.id
}

\begin{abstract}
Every case of premeditated murder carried out by someone must be motivated by certain problems between the perpetrator and the victim that made the perpetrator plan the murder. The purpose of this study is to find out psychological dynamics such as what makes a person commit an act of murder. This study uses a case study method with a qualitative approach. Participants in this study amounted to one person, namely Agus (not real name), a prisoner in a premeditated murder case who was served a punishment at the $X$ penitentiary. In the process, this study used observations, interviews and psychological testing tools that would help researchers in dynamizing participants. The results of this study indicate that Aguscommitted murder was motivated by feelings of jealousy towards his wife, poor coping, inconsistent parenting, bad living environment and imitative behavior make Acapable of killing.
\end{abstract}

Keywords: psychological dynamics; premeditated murder; inmates

\begin{abstract}
Abstrak
Setiap kasus pembunuhan berencana yang dilakukan oleh seseorang pasti dilatarbelakangi oleh permasalahan-permasalahan tertentu antara pelaku dan korban yang membuat pelaku merencanakan pembunuhan tersebut. Tujuan dari penelitian ini adalah untuk mengetahui dinamika psikologis seperti apayang membuat seseorang dalam melakukan suatu tindakan pembunuhan. Penelitian ini menggunakan metode studi kasus dengan pendekatan kualitatif. Partisipan pada penelitian ini berjumlah satu orang yaitu A seorang narapidana kasus pembunuhan berencana yang sedang menjalani hukuman di Lapas X. Pada prosesnya, penelitian ini menggunakan observasi, wawancara dan alat tes psikologi yang akan membantu peneliti dalam
\end{abstract}


mendinamikan partisipan. Hasil dari penelitian ini menunjukan bahwa A melakukan pembunuhan dilatarbelakangi oleh perasaan cemburu terhadap sang istri, coping yang buruk, pola asuh orang tua yang inkonsisten, lingkungan tinggal sekitar yang buruk dan adanya perilaku meniru membuat diri A mampu melakukan pembunuhan.

Kata kunci: dinamika psikologis; pembunuhan berencana; narapidana

\section{Pendahuluan}

Badan Pusat Statistik Indonesia (2018) menyatakan bahwa pada tahun 2015 terdapat 352.936 kasus tindakan kriminal. Jumlah ini meningkat sebanyak 357.197 kasus pada tahun 2016 dan menurun kembali pada tahun 2017 menjadi 334.652 kasus. Kartono (1999) menjelaskan kriminalitas sebagai suatu tindak kriminal yang segala sesuatu perbuatannya melanggar hukum dan melanggar norma-norma sosial, selain merugikan penderita atau korban juga sangat merugikan masyarakat yaitu berupa hilangnya keseimbangan ketentraman dan ketertiban. Menurut hurwitz (1986) ada beberapa faktor dalam diri yang menyebabkan seseorang melakukan tindakan kriminal yaitu faktor biologik atau keturunan, faktor pembawaan kriminal dan umur. Hurwitz (1986) juga menjelaskan bahwa kriminalitas dapat disebabkan oleh faktor diluar diri pelaku seperti faktor lingkungan, keadaan ekonomi (kemiskinan), pendidikan, bacaan harian ataupun film.

Holmes (dalam Towel dan Crighton, 2003) menjelaskan bahwa ada beberapa ciri khas yang muncul pada orang yang melakukan tindak kriminal 1) Mereka cenderung tinggi dalam urutan kelahiran keluarga, sering kali menjadi anak pertama, 2) Rata-rata IQ adalah rata-rata atau di atas rata-rata, namun sering bekerja dalam pekerjaan di bawah kemampuan mereka, 3) Mereka memiliki sejarah bekerja dalam pekerjaan yang terampil namun riwayat pekerjaan mereka tidak merata, 4) Mereka mengalami stresor situasional, seperti kesulitan interpersonal, keluarga atau pekerjaan terkait sebelum melakukan pelanggaran, 5) Mereka cenderung mahir secara sosial dan sering tinggal dengan pasangan, 6) Mereka mungkin mengalami depresi atau marah pada saat melakukan pelanggaran, 7) Mereka cenderung memiliki dan 
menggunakan mobil dalam pelanggaran, 8) Mereka cenderung menyimpan 'suvenir' dari pelanggaran tersebut, 9) Mereka cenderung menyimpan kliping berita dari pelanggaran tersebut.

Salah satu kasus kriminal yang sangat sering terjadi adalah kasus penghilangann nyawa seseorang atau pembunuhan. Badan Pusat Statistik (2018) menyatakan bahwa jumlah kasus kejahatan terhadap nyawa dari tahun 2015 hingga 2017 cenderung fluktatif. Pada tahun 2015 terjadi 1.491 kasus pembunuhan dan tahun 2017 terjadi 1.150 kasus pembunuhan. Kasus pembunuhan adalah kasus yang sangat serius karena menyebabkan nyawa seseorang sampai menghilang. Dalam setiap kasus pembunuhan, ada dua hal yang harus diperhatikan yaitu apakah pembunuhan tersebut direncanakan oleh korban atau pembunuhan tersebut terjadi karena ketidaksengajaan seperti adanya pertengkaran emosional antara pelaku dan korban.

Maraknya kasus pembunuhan yang terjadi dapat disebabkan oleh motif-motif tertentu seperti perampokan, perselisihan, pemerkosaan, pembagian harta warisan, balas dendam dan perasaan cemburu. Selain itu, lingkungan yang kurang baik, tingkat pendidikan yang rendah, perekonomian yang buruk juga menjadi salah satu penyebab seseorang melakukan pembunuhan. Wiyata (dalam Priani 2009) menyebutkan bahwa, agama dan harga diri dapat menjadi salah satu motif seseorang dalam melakukan pembunuhan.

Berdasarkan wawancara dan observasi yang telah peneliti lakukan pada partisipan A di lembaga permasyarakatan X, diketahui partisipan A terkena pasal 340 UU KUHP terkait dengan pembunuhan berencana yaitu telah menghabisi nyawa selingkuhan sang istri.Kasus pembunuhan ini dilatarbelakangi oleh rasa kecemburuan A terhadap istrinya yang berselingkuh dengan laki-laki dari desa lain. Perselingkuhan ini bukan pertama yang terjadi, namun sudah yang kedua kalinya dilakukan oleh istri A. Pada perselingkuhan yang pertama, A mampu memaafkan istrinya walaupun sempat bersitegang dengan selingkuhan istrinya. Pada perselingkuhan yang kedua inilah, A melakukan pembunuhan kepada selingkuhan istrinya karena istrinya sudah dianggap menelantarkan anak-anak dirumah dan 
memilih untuk tinggal di rumah selingkuhannya. Sebelum terjadinya pembunuhan, A pernah melihat istrinya diantar dan dijemput bekerja oleh selingkuhan tersebut. Pada saat itu A hanya bisa terdiam saja melihat hal tersebut. Selain itu, selingkuhan istri A pun dengan terang-terangan sempat mendatangi A dan menunjukan foto, telepon dan pesan dari istrinya. Selingkuhan istri A juga sempat mengatakan hal-hal yang membuat A sakit hati seperti A adalah orang yang susah dalam mencari uang sedangkan selingkuhannya tersebut gampang dalam mencari uang karena ia adalah salah satu perangkat desa. Akhirnya karena perasaan cemburu, kesal dan dendam yang begitu besar ditambah dengan lingkungan sekitar A yang memanaskan dirinya, ia melakukan aksi pembunuhannya dengan sadis. A mengakhiri nyawa selingkuhan istrinya dengan melakukan pembacokan berkali-kali menggunakan celurit. Setelah aksi pembunuhannya selesai, A sempat tertidur terlebih dahulu dirumah saudaranya karena ia merasa lelah lalu keesokan paginya ia menyerahkan diri ke kantor polisi.

Di Indonesia, pasal 340 Undang Undang KUHP sudah jelas menerangkan bahwa Barang siapa sengaja dan dengan rencana lebih dahulu merampas nyawa orang lain, diancam dengan pidana mati atau pidana penjara seumur hidup atau selama waktu tertentu, paling lama 20 tahun. Walaupun ancaman hukuman yang ditawarkan sudah jelas, namun masih saja kasus pembunuhan dimasyarakat tetap marak terjadi sehingga peneliti tertarik lebih dalam lagi menggali dinamika psikologis seperti apa yang dialami oleh seseorang sehingga ia mampu melakukan tindak pidana pembunuhan.

\section{Metode}

Metode yang digunakan pada penelitian ini adalah metode studi kasus. Jumlah partisipan pada penelitian ini berjumlah satu orang narapidana yang terjerat kasus pembunuhan berencana (pasal 340 UU KUHP) di lembaga pemasyarakatan X. Partisipan dipilih dengan menggunakan teknik purposive sampling yaitu sebuah teknik sampling yang pemilihan partisipannya berdasarkan kriteria-kriteria tertentu (Sugiyono, 2013). 
Pada penelitian ini, ada beberapa teknik asesmen yang digunakan peneliti untuk mendapatkan data yang mampu menggambarkan dinamika psikologis pada partisipan. Adapun teknik yang digunakan yaitu 1) observasi untuk mengetahui gambaran perilaku yang partisipan tunjukkan selama berhadapan dengan peneliti diproses penelitian; 2) wawancara digunakan untuk menggali informasi dan hal-hal apa saja yang berkaitan dengan riwayat kehidupan partisipan dari masa kanak-kanak hingga saat ini ketika melakukan pembunuhan 3) tes psikologi yang meliputi tes grafis, WWQ (Woodworth Questioner), SSCT (Sack's Sentence Completion Test), Hare Psychophaty Inventory, WB (Wechsler Bellevue Intelligence Scale), TAT (Thematic Apperception Test)dan Antisocial Personality DisorderChecklist berdasarkan DSM V (2013)yang digunakan untuk menggambaran kepribadian, permasalahan dan diagnosis pada partisipan; 4) dokumen atau arsip yang berkaitan, seperti dokumen putusan.

\section{Hasil dan Pembahasan}

Berdasarkan hasil pemeriksaan checklist Antisocial Personality DisorderChecklist pada DSM V (2013), A di diagnosis mengalami gangguan antisocial personality disorderkarena telah memenuhi 3 dari 4 kriteria yang ada pada DSM V (lihat tabel 1). Antisocial personality disorderadalah gangguan kepribadian antisosial yang dimulai pada masa remaja sebagai kelainan perilaku yang dimulai seperti pembolosan, melarikan diri dari rumah, sering berbohong, pencurian, pembakaran, penghancuran propertis yang disengaja. Kepribadian antisosial pada orang dewasa menunjukkan adanya perilaku yang tidak bertanggung jawab serta tidak dapat bekerja secara konsisten, melanggar undang-undang, agresif secara fisik, gagal membayar hutang, dan bersikap sembrono. Selain itu juga menunjukkan manipulatif dan tidak menunjukkan kebenaran atau penyesalan atas kesalahan yang dilakukannya. Perilaku ini muncul sejak masa kanak-kanak dan terus berlanjut hingga dewasa (Neale, Davison, \& Haaga, 1996). 
Berdasarkan hasil pemeriksaan tes psikologi yang telah dilakukan, maka dapat disimpulkan bahwa tindakan kriminal berupa pembunuhan berencana yang dilakukan oleh A disebabkan oleh beberapa faktor diantaranya adalah kurangnya pemahaman terhadap norma sosial dan konsekuensi dari apa yang dilakukan. Orang tua yang tidak pernah mengajarkan nilai dan norma ditambah ayah yang permisif dan ibu yang cenderung otoriter membuat A tidak mempunyai kontrol dari orang tuanya atau dari dirinya. Sehingga dalam melakukan pembunuhan, A sama sekali tidak merasa bersalah dan justru bangga atas apa yang ia lakukan. Menurut Hurlock (1980) ada beberapa faktor yang mempengaruhi kontrol diri seseorang yaitu orientasi religius, pola asuh orang tua dan faktor kognitif. A diasuh dengan pola asuh yang inkonsisten antara ayah dan ibunya. A juga tidak ditanamkan nilai religiusitas oleh kedua orang tuanya dan dari segi intelektual, A memiliki kemampuan intelektual yang dapat dikatakan kurang. Intelektual yang kurang memadai membuat kemampuan A dalam menyelesaikan masalah dapat dikatakan kurang, sehingga jika ada masalah, A tidak pernah berusaha menyelesaikan masalahnya dan cenderung membiarkan saja.

Dalam hal berelasi, A kurang mampu dalam menciptakan sebuah kualitas relasi yang hangat dan cenderung hanya dipermukaan saja. Hal ini disebabkan oleh A yang merupakan orang pendiam dan tidak suka mencari masalah dengan orang lain. Sampai akhirnya istrinya berselingkuh, A mendapat tekanan dari orang-orang disekitarnya dan sudah tidak tahan menahan rasa malu, sehingga A tidak dapat mengontrol lagi perilaku lalu melakukan pembunuhan terhadap selingkuhan istrinya. Menurut Adler (dalam Feist dan Feist, 2006), saat inferiority seseorang terus ditekan dan ketika seseorang tersebut tidak mampu lagi untuk menahan tekanan tersebut, maka yang muncul adalah superiority dari seseorang tersebut.

Selain itu, kontrol terhadap diri yang kurang baik, membuat A tidak berpikir panjang dalam melakukan aksi pembunuhan tersebut. Gottfredson dan Hirschi (dalam Wikstrom dan Treiber, 2007) mengatakan bahwa kontrol diri yang rendah adalah karakteristik utama penyebab individu berperilaku kriminal. Hurlock (1980) mengungkapkan bahwa kontrol diri seseorang dipengaruhi oleh faktor internal dan 
eksternal. Faktor internal sendiri terjadi melalui pengalaman evolusi, kontrol emosi yang sehat yang di dapat dari kekuatan ego yang baik, dalam arti mampu untuk menahan diri dan tindakan luapan emosi. Sedangkan untuk faktor eksternal meliputi dari keadaan sosio-emosional lingkungan individu tersebut, terutama didalam lingkungan keluarga dan juga teman sebaya, karena dari faktor pendukung tersebut seseorang mencapai kematangan emosi.

A masih kurang mampu dalam mengontrol emosi yang ada dalam dirinya sehingga saat emosi itu tidak dapat dikontrol akan muncul perilaku yang diluar kontrol pula. Menurut Gottman dan Katz (dalam Anggreiny,2014) regulasi emosi merujuk pada kemampuan untuk menghalangi perilaku tidak tepat akibat kuatnya intensitas emosi positif atau negatif yang dirasakan dan mengorganisir diri sendiri untuk mengatur perilaku yang tepat untuk mencapai suatu tujuan. Apabila seseorang memiliki kemampuan ketrampilan regulasi emosi yang baik maka reaksi yang akan dikeluarkan pun akan positif, berbeda apabila ketrampilan regulasi emosinya buruk maka reaksi yang keluar pun berupa tindakan yang negatif dan agresif.

Gambar 1. Gambaran Dinamika Partisipan A dalam Melakukan Pembunuhan

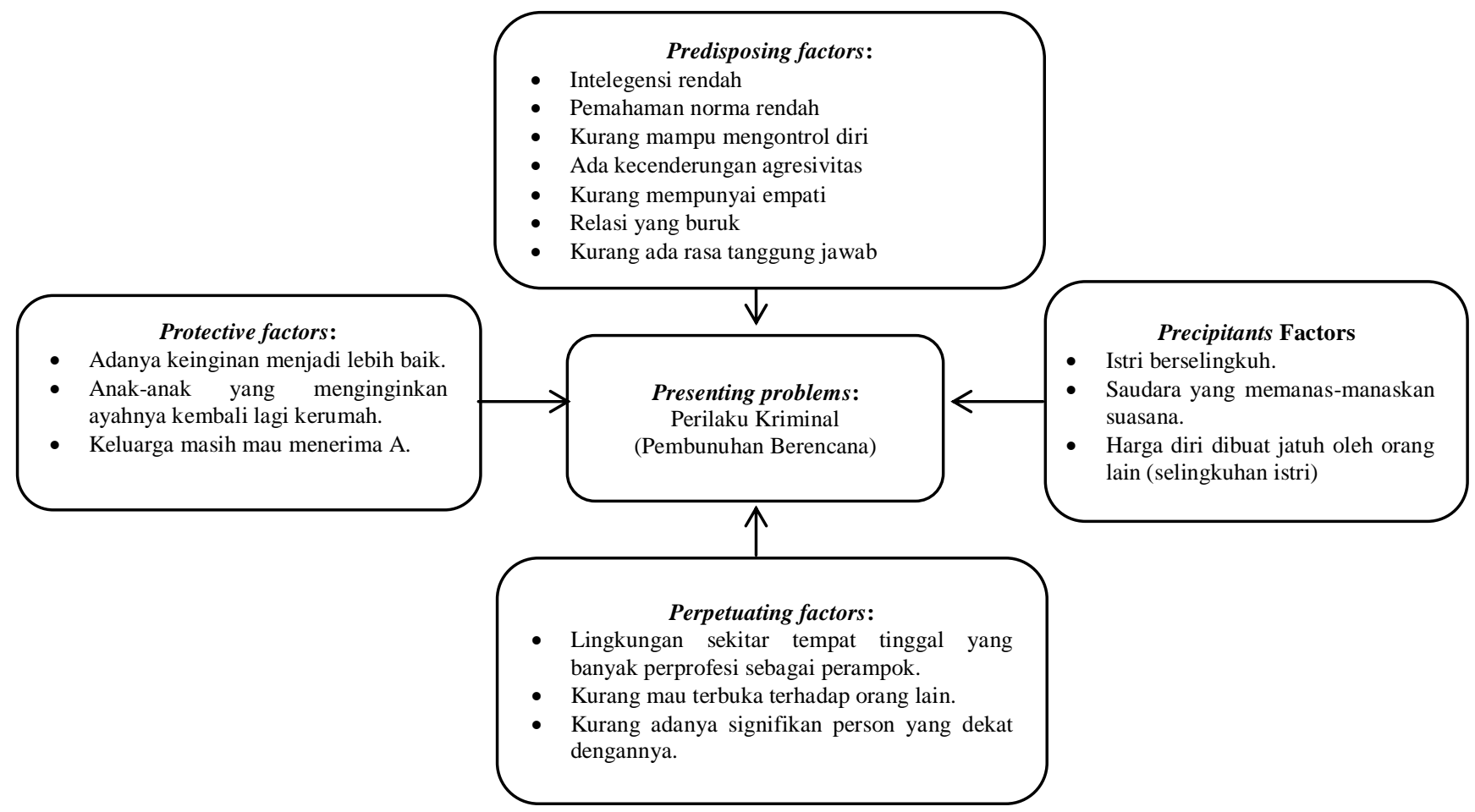


Tabel 1. Antisocial Personality Disorder Checklist

\begin{tabular}{|c|c|c|c|c|c|}
\hline No & $\begin{array}{l}\text { Kriteria Umum Antisocial } \\
\text { Personality Disorder }\end{array}$ & $\begin{array}{c}\text { Ada }(\sqrt{ }) \\
/ \\
\text { Tidak } \\
(-)\end{array}$ & $\begin{array}{l}\text { Sumber } \\
\text { Data }\end{array}$ & $\begin{array}{c}\text { Gejala yang } \\
\text { nampak pada } \\
\text { klien atau } \\
\text { penyebab } \\
\text { terbentuknya }\end{array}$ & $\begin{array}{c}\text { Dampak/tingkat } \\
\text { keparahan }\end{array}$ \\
\hline 1. & $\begin{array}{l}\text { Pola yang meresap dalam } \\
\text { diri individu dan melanggar } \\
\text { hak orang lain yang terjadi } \\
\text { sejak individu berusia } 15 \\
\text { tahun, seperti yang } \\
\text { ditunjukkan oleh } 3 \text { atau } \\
\text { lebih sebagai berikut : } \\
\text { 1. Gagal mematuhi norma } \\
\text { sosial sehubungan } \\
\text { dengan perilaku yang } \\
\text { seharusnya, seperti yang } \\
\text { ditunjukkan oleh } \\
\text { tindakan yang dilakukan } \\
\text { berulang kali yang } \\
\text { merupakan dasar } \\
\text { penangkapan. } \\
\text { 2. Ketidaktahuan, seperti } \\
\text { yang ditunjukkan oleh } \\
\text { pembohong berulang, } \\
\text { penggunaan alias, atau } \\
\text { menipu ornag lain untuk } \\
\text { keuntungan atau } \\
\text { kesenangan pribadi. } \\
\text { 3. Impulsif atau gagal } \\
\text { merencanakan ke depan } \\
\text { 4. Iritabilitas dan } \\
\text { agresivitas, seperti yang } \\
\text { ditunjukkan adanya } \\
\text { perkelahian fisik } \\
\text { ditunjukkan oleh sikap } \\
\text { acuh tak acuh terhadap } \\
\text { orang lain atau } \\
\text { merasionalisasi karena } \\
\text { menyerang secara fisik. } \\
\text { 5. Kurang memperhatikan } \\
\text { keselamatan diri sendiri } \\
\text { maupun orang lain } \\
\text { Tidak bertanggung } \\
\text { jawab secara konsisten, } \\
\text { adanya kegagalan } \\
\text { berulang untuk } \\
\text { mempertahankan } \\
\text { perilaku kerja yang } \\
\text { konsisten atau } \\
\text { menghormati kewajiban } \\
\text { Tidak adanya } \\
\text { fongalan, seperti yang }\end{array}$ & $\sqrt{ }$ & wawancara & 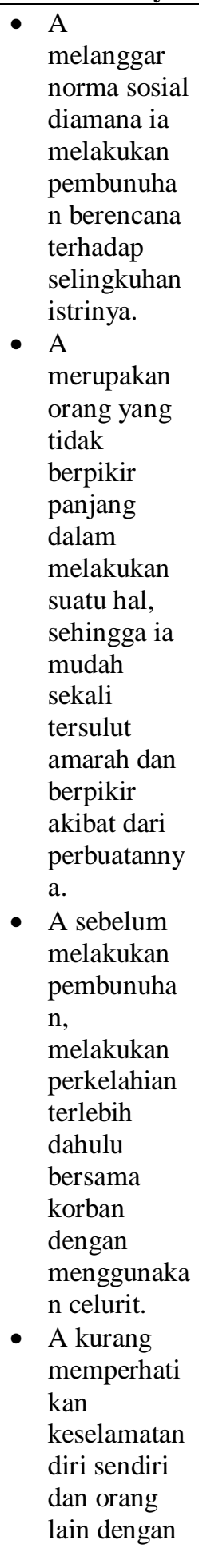 & $\begin{array}{l}\text { A dikenakan } \\
\text { pasal } 340 \text { UU } \\
\text { KUHP terkait } \\
\text { dengan } \\
\text { pembunuhan } \\
\text { berencana dan } \\
\text { dihukum hingga } 6 \\
\text { tahun. }\end{array}$ \\
\hline
\end{tabular}




\begin{tabular}{|c|c|c|c|c|c|}
\hline No & $\begin{array}{l}\text { Kriteria Umum Antisocial } \\
\text { Personality Disorder }\end{array}$ & $\begin{array}{c}\text { Ada }(\sqrt{ }) \\
\text { Tidak } \\
(-)\end{array}$ & $\begin{array}{l}\text { Sumber } \\
\text { Data }\end{array}$ & $\begin{array}{c}\text { Gejala yang } \\
\text { nampak pada } \\
\text { klien atau } \\
\text { penyebab } \\
\text { terbentuknya }\end{array}$ & $\begin{array}{l}\text { Dampak/tingkat } \\
\text { keparahan }\end{array}$ \\
\hline & $\begin{array}{l}\text { telah menyakiti, } \\
\text { menganiaya, atau } \\
\text { mencuri dari orang lain. }\end{array}$ & & & $\begin{array}{l}\text { melakukan } \\
\text { perkelahian } \\
\text { yang } \\
\text { menyebabka } \\
\text { n hilangnya } \\
\text { nyawa } \\
\text { korbannya. } \\
\text { - A setelah } \\
\text { melakukan } \\
\text { pembunuha } \\
\text { n sama } \\
\text { sekali tidak } \\
\text { menyesali } \\
\text { perbuatanny } \\
\text { a dan malah } \\
\text { merasa } \\
\text { bangga atas } \\
\text { apa yang } \\
\text { dilakukanny } \\
\text { a. }\end{array}$ & \\
\hline 2. & $\begin{array}{l}\text { Individu setidaknya } \\
\text { berumur } 18 \text { tahun }\end{array}$ & $\sqrt{ }$ & $\begin{array}{l}\text { Wawancar } \\
\text { a }\end{array}$ & $\begin{array}{l}\text { Saat melakukan } \\
\text { pembunuhan A } \\
\text { berumur } 33 \\
\text { tahun }\end{array}$ & $\begin{array}{l}\text { A dikenakan } \\
\text { pasal } 340 \text { UU } \\
\text { KUHP terkait } \\
\text { dengan } \\
\text { pembunuhan } \\
\text { berencana dan } \\
\text { dihukum hingga } 6 \\
\text { tahun. }\end{array}$ \\
\hline 3. & $\begin{array}{l}\text { Adanya bukti kelainan } \\
\text { perilaku dengan onset } \\
\text { sebelum usia } 15 \text { tahun }\end{array}$ & $\sqrt{ }$ & $\begin{array}{l}\text { Wawancar } \\
\text { a }\end{array}$ & $\begin{array}{l}\text { - Saat kecil A } \\
\text { sering dibully } \\
\text { oleh teman- } \\
\text { temannya. } \\
\text { - A juga sering } \\
\text { diajak } \\
\text { berkelahi } \\
\text { oleh teman- } \\
\text { temannya, } \\
\text { namun A } \\
\text { selalu } \\
\text { menghindar } \\
\text { dari teman- } \\
\text { temannya. }\end{array}$ & $\begin{array}{l}\text { Cukup sering } \\
\text { diajak berkelahi } \\
\text { atau di bully. }\end{array}$ \\
\hline 4. & $\begin{array}{l}\text { Terjadinya perilaku } \\
\text { antisosial tidak semata-mata } \\
\text { selama menjalani } \\
\text { skizofrenia atau gangguan } \\
\text { bipolar }\end{array}$ & - & \multicolumn{3}{|c|}{$\begin{array}{c}\text { A tidak mengalami gangguan bipolar atau } \\
\text { skizofrenia }\end{array}$} \\
\hline
\end{tabular}




\section{Kesimpulan dan Saran}

\section{Kesimpulan}

Kasus pembunuhan berencana yang dilakukan oleh A berakar dari rasa cemburu yang dialami oleh A terhadap istrinya. Intelegensi yang rendah, kurangnya pemahaman terhadap norma dan nilai serta tidak mampu dalam mengontrol diri membuat A mudah terpengaruh orang lain sehingga memunculkan perilaku yang negatif yaitu dengan melakukan pembunuhan.

\section{Saran}

Ada baiknya partisipan A lebih mampu untuk mengontrol dirinya sendiri dan berpikir dua kali dalam melakukan suatu tindakan agar permasalahan yang sama tidak terulang dikemudian hari kembali. Selain itu, kelak ketika sudah keluar dari lembaga permasyarakatan ada baiknya partisipan mencari lingkungan baru yang baik agar tidak terpengaruh kembali oleh lingkungan sekitarnya yang kurang baik.

\section{DAFTAR PUSTAKA}

Anggreiny, N. (2014). Rational Behaviour Therapy (REBT) untuk Meningkatkan Regulasi Emosi pada Remaja Korban Kekerasan Seksual, (Tesis: Psikologi Profesi Kekhususan Klinis Anak Universitas Sumatera Utara, 2014), h. 22

Badan Pusat Statistik. (2018). Statistik Kriminal 2018. Jakarta: Badan Pusat Statistik

DSM V. (2013). Diagnostic and statistical manual of mental disorders fiftth edition. Washington DC: American Psychiatric Association.

Feist, J., \& Feist, G. (2006). Theories of Personality. New York: McGraw-Hill.

Hurlock, E.B. (1980). Psikologi perkembangan: suatu pendekatan sepanjang rentang kehidupan. Jakarta: Penerbit Erlangga.

Hurwitz, S. (1986). Kriminologi. Terjemahan oleh Ny. L. Moeljatno, SH.. Jakarta: PT Bina Aksara. 
Kartono, K. (1999). Patologi Sosial. Jakarta: Raja grafindo Persada

Neale, J.M., Davidson, G.C \& Haaga, D.A.F. (1996). Exploring abnormal psychology.New York: John Wiley \& Sons

Priani, I. (2009). Dinamika Psikologis Perilaku Membunuh. Skripsi (tidak diterbitkan). Universitas Muhammadiyah Surakarta. http://eprints.ums.ac.id/5 898/1/F100030111.pdf.

Sugiyono. (2013). Metode Penelitian Pendidikan Pendekatan Kuantitatif, Kualitatif, dan R\&D. Bandung: Alfabeta

Towel, G.J \& Crighton, D.A (2010). Forensic Psychology. London: BPS and Blackwell Publishing.

Wikström, P-O H. \& Treiber, K., (2007). The role of self-control in crime causation: Beyond Gottfredson and Hirschi's general theory of crime. European Journal of Criminology, 4(2), pp.237-264. 